African Crop Science Journal by African Crop Science Society is licensed under a Creative Commons Attribution 3.0 Uganda License. Based on a work at www.ajol.info/ and www.bioline.org.br/cs DOI: https://dx.doi.org/10.4314/acsj.v27i2.5

\title{
POTENTIAL FOR YIELD LOSS REDUCTION AND PROFITABILITY ASSESSMENT OF PESTICIDE CONTROL OF GROUNDNUT LEAF MINER AMONG SOYBEAN GENOTYPES
}

\author{
M. NAMARA, J. KARUNGI, R. EDEMA, P. GIBSON and P.TUKAMUHABWA
}

Department of Agricultural Production, School of Agricultural sciences, Makerere University, P. O. Box 7062, Kampala, Uganda

Corresponding author: mnamara@caes.mak.ac.ug

(Received 18 November 2016; accepted 13 May 2019)

\begin{abstract}
Groundnut leaf miner (GLM) is currently a threat to soybean production in Uganda due to the great yield losses as a result of the severe damage it causes on leaves leading to reduced photosynthetic area. GLM is a fairly new pest on soybean in Uganda, having initially been observed in soybean fields in 2011 in eastern Uganda. The objective of this study was to determine the yield loss caused by the groundnut leaf miner and effectiveness and profitability of commonly used pesticides for the control of the groundnut leaf miner (Aproaerema modicella Deventer) (GLM), when tested with popular soybean (Glycine max) genotypes grown in Uganda. In a split plot RCBD design, pesticide protection (treated vs. untreated) formed the main plots; and six commercial soybean varieties (Maksoy $1 \mathrm{~N}, 2 \mathrm{~N}$, $3 \mathrm{~N}, 4 \mathrm{~N}, 5 \mathrm{~N}$; and Namsoy $4 \mathrm{M}$ ) as subplots. The study was done in two locations in eastern Uganda (Iki Iki District Agricultural Training and Information Centre (Iki Iki DATIC) and National Semi-Arid Resources Research Institute, Serere (NaSARRI) with two planting rounds at Iki Iki. These sites were chosen because they are hot spots for GLM. GLM severity and soybean yield were significantly affected by the pesticide protection. Overall, percentage grain yield losses caused by GLM on the different soybean varieties ranged from $37.3 \%$ to $65.7 \%$ and the highest loss was displayed by Maksoy $5 \mathrm{~N}$. Grain yield loss recorded at Iki Iki DATIC $(53.1 \%)$ was remarkably higher than that recorded at the NaSARRI (49.1\%). Economic analysis showed marginal returns to be dependent on location, with the Iki Iki DATIC having 0.6 and NaSARRI 1.1. This study has shown that the groundnut leaf miner, a recently emergent pest of soybean is becoming a big threat to soybean production and that chemical control alone may not be economical in managing the pest.
\end{abstract}

Key Words: Aproaerema modicella, Glycine max, marginal returns, Uganda

\section{RÉSUMÉ}

La mineuse de feuilles d'arachide (MFA) constitue actuellement une menace pour la production de soja en Ouganda en raison des pertes de rendement considérables dues aux dégâts importants causés aux feuilles, ce qui a entraîné une réduction de la surface photosynthétique. Le MFA est un ravageur 
relativement nouveau sur le soja en Ouganda. Il avait d'abord été observé dans des champs de soja en 2011 dans l'est de l'Ouganda. L'objectif de cette étude était de déterminer la perte de rendement causée par la mineuse de feuilles d' arachide et l'efficacité et la rentabilité des pesticides couramment utilisés pour lutter contre la mineuse de feuilles d'arachide (Aproaerema modicella Deventer) (MFA), lorsqu'il était testé avec du soja très répandu (Glycine max ) génotypes cultivés en Ouganda. L'essai a été installé suivant un dispositif split plot en parcelles divisées, la protection antiparasitaire (traitée ou non traitée) constituait les parcelles principales; et six variétés commerciales de soja (Maksoy 1N, $2 \mathrm{~N}, 3 \mathrm{~N}, 4 \mathrm{~N}, 5 \mathrm{~N}$; et Namsoy 4M) en sous-parcelles. L'étude a été réalisée dans deux regions de l'est de l'Ouganda (Centre de formation et d'information agricoles du district d'Iki Iki (Iki Iki DATIC) et Institut national de recherche sur les ressources semi-arides de Serere (NaSARRI), avec deux fois de plantation à Iki Iki. Ces sites ont été choisis parceque ce sont des regions très menaces par MFA. La protection contre les pesticides a eu un effet important sur la sévérité du MFA et le rendement du soja. Generalement, le pourcentage de pertes de rendement en grain causées par la sur les différentes variétés de soja variait de $37,3 \%$ à $65,7 \%$ et la perte la plus élevée a été montrée par Maksoy 5N. La perte de rendement en grains trouvée à Iki Iki DATIC $(53,1 \%)$ était remarquablement supérieure à celle trouvée à NaSARRI $(49,1 \%)$. L'analyse économique a montré que les rendements marginaux dépendaient de la localisation, l'Iki Iki DATIC étant à 0,6 et NaSARRI à 1,1 . Une étude a montré que la mineuse de feuilles d'arachide, un ravageur du soja récemment apparu, constituait une menace majeure pour la production de soja et que la lutte chimique à elle seule pouvait ne pas être rentable pour lutter contre ce ravageur.

Mots Clés: Aproaerema modicella, Glycine max, rendements marginaux, Ouganda

\section{INTRODUCTION}

Soybean (Glycine max) is a crop that is grown worldwide (FAO, 2015).The crop is valued for being highly nutritious, with about $40 \%$ protein and $20 \%$ oil, that are key for human and animal nutrition (Gibson and Garren, 2005; IITA, 2009; Qiu and Chang, 2010). Despite its growing importance in Uganda, soybean production is currently under a threat caused by the groundnut leaf miner (GLM), Aproarema modicella Deventer (Lepidoptera: Gelechiidae), a pest that hitherto has been incognito in soybean production. The pest is especially prevalent in the second growing season (August-December) in eastern Uganda (Okello, et al., 2013).

The leaf miner causes yield losses ranging from 50 to $100 \%$ on groundnut (Kenis and Cugala, 2006; Cugala et al., 2010); and at empirically unknown levels in soybean, owing to lack of coordinated research on this pest. Emphasis in management of the pest has been placed on chemical control, which has been found variably effectiveness against GLM in groundnuts, with yield increases of about 60\% (Cugala et al., 2010; Praveen et al., 2011a). With its recent invasion and increasing devastation of soybean, it is imperative that an independent evaluation of the most successful pesticide candidates of GLM in groundnuts, is done to establish their effective and profitability on soybean. Knowledge on the extent of damage on different soybean genotypes will also guide the breeding programme on the resource requirements. The objective of this study, therefore, was to determine yield losses caused by the groundnut leaf miner and the effectiveness and profitability of commonly used pesticide for the control of GLM in groundnuts, when tested with popular soybean genotypes grown in Uganda.

\section{MATERIALS AND METHODS}

Six locally bred commercial soybean varieties, Namsoy 4M, Maksoy 1N, Maksoy 2N, Maksoy 3N, Maksoy 4N and Maksoy 5N were used in this study. The study was conducted 
in season 2013B (since the pest only occurs in the second season), in two locations in eastern Uganda namely, Iki Iki District Agricultural Training and Information Centre, Budaka district; and the National Semi-Arid Resources Research Institute (NaSARRI) in Serere district. These locations are renowned hotspots for GLM (Personal communication, Prof. Phinehas Tukamuhabwa, Makerere University, 2013).

Site description. Iki Iki DATIC is located at $1^{\circ} 06^{\prime} \mathrm{N}-34^{\circ} 00^{\prime} \mathrm{E}$ at an altitude of 1,156 meters above sea level and receives mean annual rainfall and temperature of 1,200 $\mathrm{mm}$ and $24.7^{\circ} \mathrm{C}$, respectively; whereas NaSARRI is located at $1^{\circ} 31^{\prime} \mathrm{N}-33^{\circ} 27^{\prime} \mathrm{E}$ at an altitude of 1,139 meters above sea level, and receives mean annual rainfall and temperature of 1,972 $\mathrm{mm}$ and $24^{\circ} \mathrm{C}$, respectively. Since the pest only occurs in the second growing season, the study was repeated by staggered planting in Iki Iki where the first planting was done on the $2^{\text {nd }}$ of September 2013 and the second planting on the $10^{\text {th }}$ of October 2013. The NaSARRI site was also planted on the latter planting date.

Experimental design and treatments. The study was laid out in a randomised complete block design, in a split plot arrangement, with the pesticide regime in the main plots, and the soybean varieties in the sub-plots. Treatments were replicated three times. Two main treatment levels were used: protected (sprayed), versus unprotected (unsprayed). Spraying of the protected plots was done using a tank mixture of cypermethrin (Cyperlacer 5EC), a contact insecticide, and dimethoate (Tafgor 40EC), a systemic (which are recommended chemicals for controlling leaf miner on groundnut) so as to completely eliminate the leaf miner (Karungi et al., 2000; Nabirye et al., 2003). Spraying started 14 days after planting (DAP), the time when the leaf miner was first observed in the field; and continued once a week up to crop physiological maturity. Spraying was done during morning hours (7:00-9:00 am), using a knapsack sprayer.

The soybean varieties (Maksoy $1 \mathrm{~N}, 2 \mathrm{~N}$, $3 \mathrm{~N}, 4 \mathrm{~N}, 5 \mathrm{~N}$ and Namsoy $4 \mathrm{M}$ ) were planted at a spacing of $60 \mathrm{~cm}$ between rows and $5 \mathrm{~cm}$ within rows. Each plot had 4 rows measuring $5 \mathrm{~m}$. The plots were separated by paths of 1 $\mathrm{m}$ apart and $1.8 \mathrm{~m}$ between the main plots. The experiment was hand hoe weeded twice, in each of the locations, first at 3 weeks and then at 6 weeks after planting. The experiment was implemented in the field under natural infestation.

GLM severity. Severity of damage caused by GLM was recorded using a scale of 1-5; where $1=$ no damage, $2=1-20 \%$ leaf damage, $3=$ $21-40 \%$ leaf damage, $4=41-60 \%$ leaf damage and $5=61-100 \%$ leaf damage (Praveen, et al., 2011b). Data on GLM severity were recorded from 40 days after planting and continued at an interval of 14 days for 4 consecutive times (Ramani and Lingappa, 1988). Grain yield losses from the leaf miner were estimated as the difference between grain yields from protected plots and the grain yields from unprotected plots, expressed as a percentage. Data were subjected to analysis of variance using GenStat $14^{\text {th }}$ Edition, computer package, and means were separated using Fisher's Protected Least Significant Difference (LSD) test at $5 \%$ probability level.

Profitability assessment. Cost-benefit analysis was used to calculate the marginal returns (profitability) of the pesticides used, following procedures of Alghali (1992a) and as applied by Karungi et.al. (2000) and Nabirye et.al. (2003) ( Table 1). Cost of chemical spray was estimated as one litre for dimethoate and half a litre for cypermethrin per hectare for each spray (Table 1); whereas marginal returns were computed as a ratio of the extra yield value obtained from spraying to the additional cost of the spraying with pesticide (Table 2). Marginal returns indicate the value of the yield gained from spraying in relation to the cost of 
TABLE 1. Costs of pesticide application used in calculation of marginal returns

\begin{tabular}{|c|c|c|}
\hline No. of sprays & Item & Cost \\
\hline \multirow[t]{4}{*}{1} & Pesticide ${ }^{a}$ & 54,000 \\
\hline & Labour for spraying ${ }^{\mathrm{b}}$ & 60,000 \\
\hline & Labour harvesting and threshing additional grain & 40,000 \\
\hline & Total cost & 154,000 \\
\hline \multirow[t]{5}{*}{5} & Additional pesticide & 216,000 \\
\hline & Labour for 4 more sprays & 240,000 \\
\hline & Labour harvesting and threshing ${ }^{\mathrm{c}}$ additional grain ${ }^{\mathrm{d}}$ & 160,000 \\
\hline & Total cost for one spray & 154,000 \\
\hline & Total cost & 770,000 \\
\hline \multirow[t]{5}{*}{7} & Additional pesticide & 324,000 \\
\hline & Labour for 6 more sprays & 360,000 \\
\hline & Labour harvesting and threshing ${ }^{\mathrm{c}}$ additional grain ${ }^{\mathrm{d}}$ & 240,000 \\
\hline & Total cost for one spray & 154,000 \\
\hline & Total cost & $1,078,000$ \\
\hline
\end{tabular}

Adopted from Karungi et al. (2000)

aPesticide application rate was estimated at 1 litre per hectare

${ }^{b}$ Labour calculated at 1 man-day per ha (this covered knapsack sprayer hire)

${ }^{c}$ Labour for harvesting and threshing estimated/ha

${ }^{\mathrm{d}}$ Value of soybean at the time of research at $1500 \mathrm{Ug}$. Shs. $\mathrm{kg}^{-1}, 1 \mathrm{US} \$=3500 \mathrm{Ug}$. Shs.

TABLE 2. F statistics for GLM severity across the two locations at four sampling dates

\begin{tabular}{lccccc}
\hline Source of variation & d.f. & 40 DAP & 54 DAP & 68 DAP & 82 DAP \\
\hline Location & 1 & 0.1 & 0.1 & 1.3 & 1.0 \\
Reps/ location & 4 & 1.0 & 1.0 & 1.0 & 1.0 \\
Treatment & 1 & $2332^{* *}$ & $2409^{* *}$ & $176.4^{*}$ & $340.7^{*}$ \\
Location x treatment & 1 & 0.1 & 0.1 & 1.4 & 1.0 \\
Genotype & 5 & 1.7 & 1.3 & 1.0 & 1.0 \\
Location x genotype & 5 & 1.0 & 1.0 & 1.0 & 1.0 \\
Treatment x genotype & 5 & 1.7 & 1.3 & 1.0 & 1.0 \\
Location x treatment x genotype & 5 & 0.5 & 1.8 & 1.7 & 1.0 \\
\hline
\end{tabular}

Values marked $* *$ and $*$ are significantly different at 0.01 and 0.05 probability level, respectively All interactions with location were not significant 
the spray schedule. A marginal return value less than one indicates that the increase in soybean yield does not compensate for the cost of spraying (Karungi et al., 2000). The costs associated with the spray regime used are shown in Table 1.

\section{RESULTS}

GLM severity. There was a significant effect of pesticide protection for consistency on GLM severity at all sampling dates $(\mathrm{P}<0.01)$ (Table 2, Fig. 1). Soybean plants in the pesticide-sprayed plots had a mean severity score of 1.0, whereas those in the unsprayed plots had a mean severity score of 4.2 (Fig. 1). The severity of GLM in the unsprayed plots increased significantly from 2.9 at 40 DAP to 4.3 at 54 DAP. The GLM severity score at 68 DAP and 82 DAP was 4.4 and 4.6, respectively (Fig. 1). The interactions between the pesticide treatments and genotypes; location, pesticide treatment and genotype did not significantly affect GLM severity $(\mathrm{P}>0.05)$. Study location also had no significant effect on GLM severity (P>0.05) (Table 2).

Grain yield. Pesticide protection and location had a highly significant effect $(\mathrm{P}<0.001)$ on soybean grain yield (Tables 4 and 5). The interactions between pesticide protection and genotype; location, chemical protection and genotype had no significant effect on grain yield ( $P>0.05$ ) (Table 4). Lack of pesticide administration caused grain yield losses in the order of 53.1 and $49.1 \%$, at Iki Iki DATIC and NaSARRI, respectively (Table 4).

Pesticide administration increased yield by 252 and $390 \mathrm{~kg} \mathrm{ha}^{-1}$ at Iki Iki DATIC and NaSARRI, respectively (Table 6). There was an interaction effect of pesticide application and location of the study, on soybean grain yield $(\mathrm{P}<0.01)$. Genotypic differences had no significant effect on grain yield; neither did the interaction between chemical protection and genotype $(\mathrm{P}>0.05)$. Yields were in the range of $354 \mathrm{~kg} \mathrm{ha}^{-1}$ in Maksoy $5 \mathrm{~N}$ to $520 \mathrm{~kg}$ $\mathrm{ha}^{-1}$ in Namsoy $4 \mathrm{M}$.

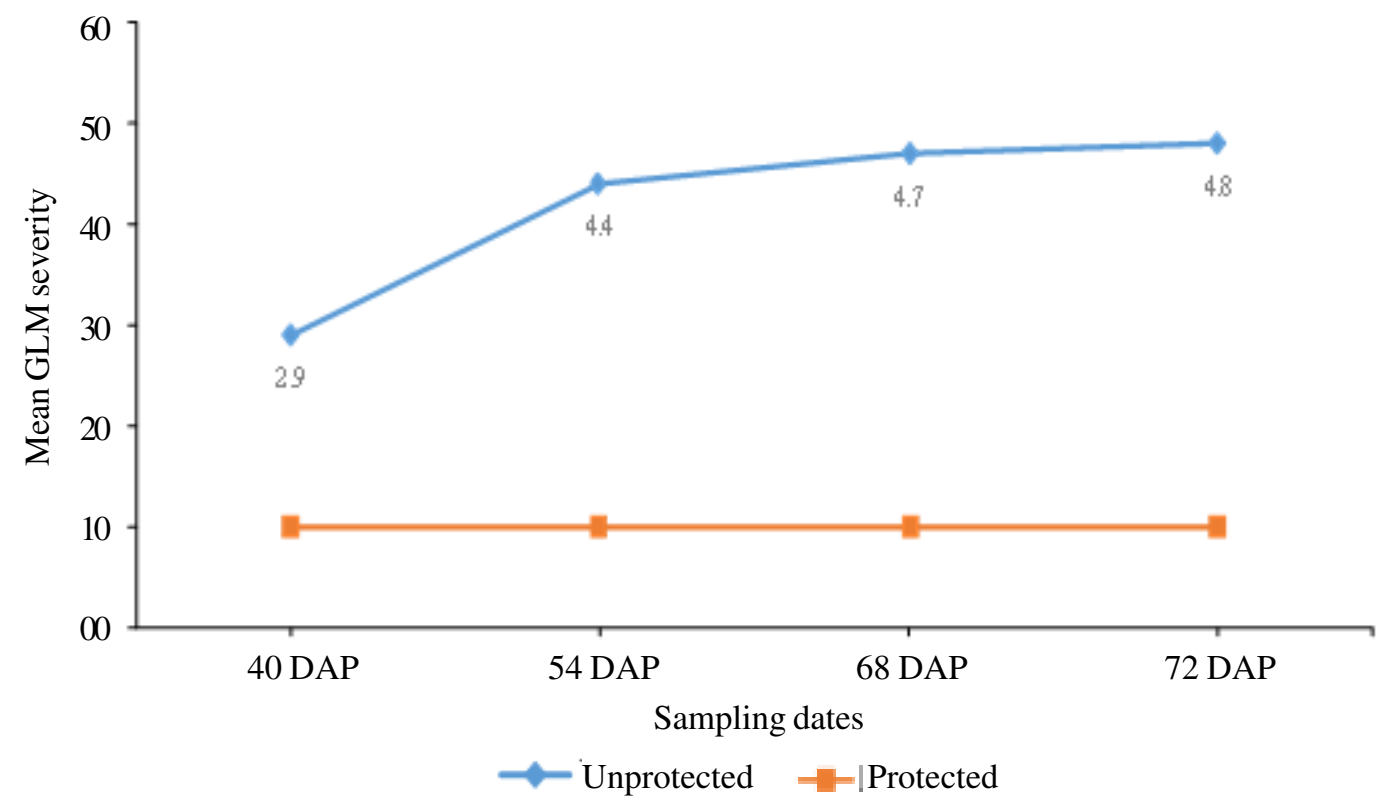

Figure 1. GLM severity means of protected vs. unprotected plots across locations for the four sampling dates $(\mathrm{DAP}=$ Days after planting). Severity scale 1-5; where $1=$ immune (no damage) $5=$ highly susceptible (61 - 100\% damage). 
TABLE 3. F statistics for effect of planting round on yield and GLM severity at the four sampling dates

\begin{tabular}{lcrcccc}
\hline Source of variation & d.f. & Yield & 40 DAP & 54 DAP & 68 DAP & 82 DAP \\
\hline Planting round & 1 & 2.2 & 0.01 & 2.4 & 1.5 & 1.0 \\
Treatment & 1 & 118.3 & $30132.4^{*}$ & $186.4^{*}$ & $167^{*}$ & $349.6^{*}$ \\
Planting round x treatment & 1 & 2.3 & 0.01 & 0.2 & 1.5 & 1.0 \\
Genotype & 5 & 1.3 & 3.6 & 2.9 & 1.3 & 1.0 \\
Planting round x genotype & 5 & 1.5 & 1.0 & 0.5 & 1.0 & 1.0 \\
Treatment x genotype & 5 & 2.2 & 3.6 & 2.9 & 1.3 & 1.0 \\
Planting round x treatment x genotype & 5 & 0.6 & 0.3 & 1.3 & 1.5 & 1.0 \\
\hline
\end{tabular}

Planting dates and all interactions with planting date were not significant

TABLE 4. F statistics for yield for treatments and varieties across locations

\begin{tabular}{lcc}
\hline Source of variation & d.f. & Yield \\
\hline Location & 1 & $341.5^{* * *}$ \\
Rep/ location & 4 & 0.54 \\
Treatment & 1 & $224.5^{* * *}$ \\
Location x treatment & 1 & $10.3^{* *}$ \\
Genotype & 5 & 2.6 \\
Location x genotype & 5 & 3.3 \\
Treatment x genotype & 5 & 1.8 \\
Location x treatment x genotype & 5 & 0.5 \\
\hline
\end{tabular}

MS- mean square; Values marked *,**,*** are significantly different at $0.05,0.01$ and 0.001 probability level respectively. All interactions with entry were not significant

Marginal returns. Marginal returns from pesticide protection at Iki Iki DATIC and NaSARRI were in the order of 0.6 and 1.1, respectively (Table 6).

\section{DISCUSSION}

GLM severity. Spraying with a tank mixture of cypermethrin and dimethoate was effective in controlling the GLM as severity was maintained at 1.0 ( $0 \%$ leaf damage) as opposed to the high severity of GLM in the unprotected plots (Table 7). However, since dimethoate use is being discontinued in Uganda, other systemic pesticides such as Chlorpyrifos 20EC or Monocrotophos 36 SL could be used as alternatives (Umesh and Krishna, 1996). The high GLM severity scores (>60\% leaf damage) in unprotected plots is evidence that GLM can cause serious damage to soybean if left uncontrolled (Table 7). This damage caused in photosynthetic tissue reduces the surface area for light interception decreasing crop growth rate, photosynthetic partitioning and ultimately results in yield loss (Du Plessis, 2003; Kenis and Cugala, 2006) especially as it happens early in the growth cycle (14 DAP). The non-significant location and genotype effect for GLM severity indicated that GLM severity was neither determined by the 
TABLE 5. Mean yield ( $\left.\mathrm{Kg} \mathrm{ha}^{-1}\right)$ from the protected (sprayed) versus unprotected (unsprayed) plots between varieties and within each of the locations

\begin{tabular}{|c|c|c|c|c|c|c|}
\hline \multirow[t]{2}{*}{ Variety } & \multicolumn{2}{|c|}{ Iki Iki } & \multicolumn{2}{|c|}{ Serere } & \multirow{2}{*}{$\begin{array}{l}\text { Overall mean } \\
\text { yield }\left(\mathrm{kg} \mathrm{ha}^{-1}\right)\end{array}$} & \multirow{2}{*}{$\begin{array}{c}\text { Percentage } \\
\text { yield loss }\end{array}$} \\
\hline & Prot & Unprot & Prot & Unprot & & \\
\hline Maksoy 1N & 406 & 144 & 618 & 407 & 394 & 47.7 \\
\hline Maksoy 2N & 327 & 124 & 998 & 438 & 472 & 57.4 \\
\hline Maksoy 3N & 395 & 186 & 769 & 516 & 466 & 40.6 \\
\hline Namsoy 4M & 408 & 273 & 864 & 534 & 520 & 37.3 \\
\hline Maksoy 4N & 594 & 152 & 822 & 333 & 475 & 57.6 \\
\hline Maksoy 5N & 435 & 173 & 657 & 160 & 354 & 65.7 \\
\hline Mean & 427.5 & 175.3 & 788.0 & 398.0 & 447.2 & 51.0 \\
\hline $\operatorname{LSD}(0.05)$ & 162.2 & 95.8 & 254.1 & 250.8 & 219.6 & \\
\hline
\end{tabular}

LSD is least significance difference for varieties down column at 5\% probability level; Prot $=$ Protected

TABLE 6. Mean grain yields and marginal returns for the protected vs. unprotected for the two locations

\begin{tabular}{|c|c|c|c|c|c|c|}
\hline Location & Spray schedule & $\begin{array}{l}\text { Marketable } \\
\text { yield }\left(\mathrm{kg} \mathrm{ha}^{-1}\right)\end{array}$ & $\begin{array}{l}\text { Yield gain } \\
\text { over control }\end{array}$ & $\begin{array}{l}\text { Value of } \\
\text { yield gain } \\
\text { from sprayed } \\
(\text { US \$) }(V)\end{array}$ & $\begin{array}{l}\text { Cost of } \\
\text { spray } \\
\text { (US \$) } \\
\text { (CP) }\end{array}$ & $\begin{array}{l}\text { Marginal } \\
\text { returns } \\
(\mathrm{MR})\end{array}$ \\
\hline \multirow[t]{3}{*}{ Iki Iki } & No pesticide & 175.3 & & & & \\
\hline & Sprayed (7times) & 427.5 & 252 & 183.2 & 308 & 0.6 \\
\hline & $\operatorname{LSD}(0.05)$ & 57.3 & & & & \\
\hline \multirow[t]{3}{*}{ Serere } & No pesticide & 398.0 & & & & \\
\hline & Sprayed (7times) & 788.0 & 390 & 337.7 & 308 & 1.1 \\
\hline & $\operatorname{LSD}(0.05)$ & 117.2 & & & & \\
\hline
\end{tabular}

LSD = Least significance difference; Marginal returns = V/CP; MR less than 1 are not profitable: 1 US\$ $=3500 \mathrm{Ug}$. Shs.

variations in the locations nor genotypes. This implies that the two locations (Iki Iki and NaSARRI) had similar prevailing weather conditions (not recorded) since Arunachalam and Kavitha (2012) reported leaf miner incidence in groundnut is mainly influenced by the prevailing weather factors, with maximum incidence observed with the increase in maximum temperature and decrease in relative humidity, rainfall and leaf wetness. This also explains the non-significant effect of planting round on GLM severity at Iki Iki.

Grain yield. The study also showed that all the tested commercial soybean varieties are prone to damage by the GLM as grain yield 
TABLE 7. Mean GLM severity at various scoring dates for the two locations

\begin{tabular}{llcccc}
\hline & & \multicolumn{4}{c}{ GLM severity } \\
\cline { 3 - 6 } & & 40 DAP & 54 DAP & 68 DAP & 82 DAP \\
\hline \multirow{2}{*}{ Iki Iki } & No pesticide & 2.9 & 4.3 & 4.4 & 4.6 \\
& Sprayed & 1.0 & 1.0 & 1.0 & 1.0 \\
\multirow{2}{*}{ Serere } & No pesticide & 2.8 & 4.5 & 4.9 & 5.0 \\
& Sprayed & 1.0 & 1.0 & 1.0 & 1.0 \\
\multirow{2}{*}{ Average } & No pesticide & 2.9 & 4.4 & 4.6 & 4.8 \\
& Sprayed & 1.0 & 1.0 & 1.0 & 1.0 \\
\hline
\end{tabular}

Severity scale 1-5; where 1 = immune (no damage); 5 = highly susceptible (61\%-100\% damage); DAP $=$ Days after planting

losses from the unprotected plots ranged from 37 to $66 \%$. Moreover, this level of loss is a threat to the status of soybean production as a commercial venture in Uganda. In fact, growers in Mozambique are reported to have abandoned ground nut production due to GLM (Cugala et al., 2010). It is imperative to intervene in Uganda to avoid such a scenario on soybean, a crop that brings in about US\$342 earnings per hectare (Tukamuhabwa and Obua, 2015). As such, effective management strategies for GLM are critical for continued and profitable production of soybean and by inference groundnuts in the country.

Marginal returns. Results on economic analysis of chemical control of GLM showed that the NaSARRI site produced positive returns (1.1); whereas the Iki Iki DATIC site did not (0.6), implying that the value of yield gains from spraying at Iki Iki were low compared to NaSARRI. This is very evident from the low yields recorded at Iki Iki compared to the higher yields recorded at NaSARRI (Table 5). At Iki Iki, the yield realised could not justify use of the chemical. Intervention could be in form of better timing of the spraying since the results show the pest comes in much earlier than expected. Umesh and Krishna (1996) recorded highest yield and gross profit when two sprays were applied to control GLM on soybean at 30 DAP and 45 DAP. Also, efforts can be put in combining pesticide usage with other cultural practices that boost plant growth for example; intercropping with cereal crops such as sorghum, and maize or trap crops such as pearl millet and cowpea which was found to reduce infestation of GLM and increase yield in groundnut (Rajagopal and Hanumanthaswamy, 2000; Okello et al., 2016). Also manipulation of plant population was found to reduce infestation of the pest in groundnut in Tamil, Nadu India (Logiswaran and Mohanasundaram 1985). These methods could be integrated with reduced chemical applications to promote cost-effectiveness.

\section{CONCLUSION}

The groundnut leaf miner caused grain yield losses ranging from $35-66 \%$ in commercial soybean varieties in Uganda. All the commercial soybean varieties sustained appreciable GLM damage with Maksoy 5N sustaining the highest yield loss.

Chemical control though successful in controlling infestation of GLM was not always 
profitable and therefore needs to be integrated with other groundnut leaf miner control strategies for leaf miner control.

\section{ACKNOWLEDGEMENT}

This study was supported by the Alliance for a Green Revolution in Africa (AGRA) and Makerere University Centre for Soybean Improvement and Development.

\section{REFERENCES}

Alghali, A.M. 1992a. On-farm evaluation of control strategies for insect pests in cowpea with emphasis on flower thrips, Megalurothrips sjostedti Trybom (Thysanoptera: Thripidae). Tropical Pest Management 38:420-424.

Arunachalam, P. and Kavitha, Z. 2012. Response of groundnut genotypes to leaf miner (Aproaerema modicella Deventer) under field screening. IOSR Journal of Agriculture and Veterinary Science 1(2):2023.

Cugala, D., Santos, L., Botao, M. Solomone, A. and Sidumo, A. 2010. Assessment of groundnut yield loss due to the groundnut leaf miner, Aproaerema modicella infestation in Mozambique. African Crop Science Conference Proceedings. pp. 319324.

Du Plessis, H. 2003. First report of groundnut leafminer, Aproaerema modicella (Deventer) (Lepidoptera: Gelechiidae) on groundnut, soybean and lucerne in South Africa. South African Journal of Plant and soil 20:1-48.

FAO, 2015. FAOSTAT. http://www.faostat3. fao.org. Accessed 01 May 2015.

Gibson, L. and Garren, B. 2005. Origin, history and uses of soybean (Glycine max). http://www.agron.iastate.edu. Accessed 16 March 2014.

International Institute of Tropical Agriculture (IITA). 2009. Soybean (Glycine max). http://www.iita.org. Accessed 20 March 2014.
Karungi, J., Adipala, E., Kyamanywa, S. and Ogenga-Latigo. 2000. Pest management in cowpea. Part 2. Integrating planting time, plant density and insecticide application for management of cowpea insect pests in eastern Uganda. Crop Protection 19:237245.

Kenis, M. and Cugala, D. 2006. Prospects for the biological control of the groundnut leaf miner, Aproaerema modicella, in Africa. Perspectives in Agriculture, Veterinary Science, Nutrition and Natural Resources 1(032):1-9.

Logiswaran, G. and Mohanasundaram, M., 1985. Effect of intercropping, spacing and mulching in the control of groundnut leaf miner, Aproaerema modicella. Madras Agricultural Journal 72:695-700.

Nabirye, J., Namapala, P., Ogenga-Latigo, M.W., Kyamanywa, S., Wilson, H., Odeke, V., Iceduna, C. and Adipala, E. 2003. Farmer-participatory evaluation of cowpea integrated pest management (IPM) technologies in eastern Uganda. Crop Protection 22:31-38.

Okello, D. K., Monyo, E., Deom, C.M., Ininda, J. and Oloka, H.K. 2013. Groundnut production guide for Uganda: Recommended practices for farmers. National Agricultural Research Organisation. Entebbe, Uganda.

Okello, D.K., Biruma, M., Ugen, M.A., Wandulu, J.A., Anguria, P., Gayi, D., Osia, P., Ereu, S.O., Muniappan, R. and Deom, C.M. 2016. Groundnut Leafminer Factsheet. A NaSARRI-PMIL Publication. Praveen, Y.V., Kotikal, Y.B., Kumar, R. and Vijaykumar, G. 2011a. Bioefficacy of newer insecticides against Groundnut leaf miner, Aproaerema modicella Deventer in northern dry zone of Karnataka. Resistant pest management News Letter 20(2):18-22.

Praveen, Y.V., Kotikal, Y.K., Awaknavar, J.S. and Kenchangoudar, P.V. 2011b. Screening of groundnut varieties against leaf miner, Aproaerema modicella Deventer. Karnataka Journal of Agricultural Sciences 24(4):561-563. 
Qiu, L.J. and Chang, R.Z. 2010. The origin and history of soybean. In: Singh. G. (Ed.) The soybean: Botany, production and uses. pp 1-23. CABI.

Rajagopal, D. and Hanumanthaswamy, B.C. 2000. Effect of intercropping on the incidence of groundnut leaf miner, Aproaerema modicella Deventer (Gelechiidae : Lepidoptera). Madras Agricultural Journal 86(9):461-464.

Ramani, S. and Lingappa, S. 1988. Evaluation of soybean germplasm for resistance to leaf miner, Aproaerema modicella (Deventer) (Lepidoptera: Gelechiidae). Karnakata Journal of Agricultural Science 2(12):7681.

Tukamuhabwa, P. and Obua, T. 2015. Soybean production guide in Uganda

Umesh, N. and Krishna, L.N. 1996. Evaluation of insecticides for the control of Leafminer Aproaerema modicella Deventer (Lepidoptera: Gelechiidae) on soybeans. Karnakata Journal of Agricultural Sciences 9(4):622-626. 